\title{
Examination of the Technology Leadership Self-Efficacy Perceptions of Educational Managers in terms of the Self-Efficacy Perceptions of Information Technologies (Malatya Province Case)
}

\author{
İzzettin Doğan*
}

\section{Ahmet Yesevi University, Türtep Department of Educational Management and Auditing} Inspection and Evaluation in Education

\begin{tabular}{ll}
\hline \hline Article history & Educational managers self-efficacy perceptions of information \\
Received: & technology may be thought to influence technological leadership self- \\
05.06 .2018 & efficacy perceptions. However, it is seen that there is not enough research \\
Received in revised form: & on this situation in the field. In this context, the perceptions of \\
01.10 .2018 & technological leadership self-efficacy of education managers and the self- \\
Accepted: & efficacy perceptions of information technology have been discussed in \\
02.10 .2018 & this present study. In the literature, it is emphasized that the gender, age, \\
Key words: & branches, the schools where they graduate and the in-service training \\
Technology integration in & situations of education administrators and teachers are effective on \\
education, technological & different variables. These variables are considered as independent \\
leadership, Information & variables in this research. This study is a descriptive research. The study \\
Technologies, self-efficacy & group of the study consisted of 210 school principals and assistant \\
perception. & principals working in the Malatya Provincial Center. Data were collected \\
& by using Self-efficacy perception scale ( $\alpha=0.97)$ and Technology \\
& Supervisor Technology Leadership Self-efficacy Scale ( $\alpha=0.97)$. \\
& Frequency, percentage, Pearson correlation (r), t-test, one-way analysis of \\
& variance (ANOVA) and post-hoc analyzes were used in the analysis of \\
& the data. The results show that school administrators have a high level of \\
& self-efficacy perceptions of technological leadership. These perceptions \\
do not differ according to the school level, age groups and in-service & \\
training. There is a significant positive correlation between technological & leadership and IT self-efficacy perceptions.
\end{tabular}

\section{Introduction}

The characteristics of the elements that make up the educational system and its relationship with each other are very important in order to achieve its purpose successfully (Usta and Korkmaz, 2010). To achieve this success, teachers have a great role. Teachers' attitudes and behaviours towards the profession at school and the outside have the power to influence the formation of students' personalities (Usta and Korkmaz, 2010). The effectiveness of teacher behaviours in the education process can not be ignored. Considering school effectiveness, teacher competencies are more prominent in the planning of classroom 
activities than in the school's ability to realize students' learning (Demir and Bozkurt, 2011). Students are often influenced by the way teachers approach a topic in classroom instruction and the way they interpret events (Usta and Korkmaz, 2010). In addition, teachers' attitudes, habits and reactions constitute an important value for students (Usta and Korkmaz, 2010).

21. Century is defined as the age of technology. In order to comply with the requirements of this era, new approaches have been introduced in education. In order for students to learn meaningful and permanent, educational systems have emerged and reform movements have come along with them (Kaya and Yilayaz, 2013). The reforms have changed the characteristics of all the necessary elements in education, especially teachers. The fact that educational institutions have certain qualifications has come to the forefornt. Moreover, students are expected to be educated as "science literate individual", which can investigate, access and use information, make decisions effectively, cooperatively, self-confident and communicate effectively (Kaya and Yilayaz, 2013). In line with this objective, educational institutions aim to enrich the use of technology that teachers and students can use in and out of the classroom. In this context, the basic competences that teachers and managers should have include the pedagogical content knowledge as well as technological knowledge (Demir and Bozkurt, 2011). Since it is aimed that students reach information and develop an effective use ability in the light of this knowledge, today, technology integration and use of technology have gained importance in education. Technology integration in education can be expressed as the correct use of technology in the teaching process.

We can use information and communication technologies (ICT) as a tool in order to achieve goals and increase student success (Hew and Brush, 2007; Çakıroğlu, Gökoğlu and Çebi, 2015). As technological developments have increased in recent years, usage necessity of using technology has increased in education and technology integration has become necessary in education (Çakır and Yıldırım, 2009). Integration of technology into education the integration of Information Communication Technologies is becoming more and more important. With the advancement of science, technology and environmental changes are accelerating and forcing people and society to change and innovate (Kabakçı-Yurdakul, 2011). Modern societies need to adapt to these changes and take steps towards renewal. In order for education to reach its objectives, schools need to change and renew. Changing schools in accordance with these aims must be planned. For this reason, plans for the needs of the age should be created and changes should be initiated according to the needs and innovations of the age (Şahin and Aslan, 2008).

Educational managers, who are the leaders of educational institutions, play a critical role in these changes. If school administrators feel confident in using technology leadership skills and are confident in using these skills effectively, their motivation for technology integration in schools will increase and they will perform these tasks successfully (Hacifazlıoğlu, Karadeniz and Dalgıç, 2011). On the other hand, it is emphasized that the perception of selfefficacy in computer is examined as an important factor in many research and striking results are achieved (Ekici, Ekici and Kara, 2012). In this context, it may be thought that educational administrators can influence the self-efficaccy perceptions of IT technology and the selfefficacy perceptions of technological leadership. However, it is observed that there was not enough research on this situation in the area. In this study, the technological leadership and IT self-efficacy perceptions of educational managers were discussed. It is emphasized that the gender, age, branches, the schools where they graduate and the in-service training situations of education administrators and teachers are effective on different variables. In this context, these variables are considered as independent variables within the scope of this research. In 
this research, the technological leadership and it self-efficacy perceptions of educational managers were examined in terms of different variables and these two variables were described in relation to each other. No similar study was found in the field literature where these two variables were dealt with in terms of educational managers. It is thought that the research will contribute significantly to the literature

\section{Problem Statement}

What are technology leadership self-efficacy perceptions of educational managers? and How does it correlation with IT self-efficacy perceptions?

\section{Sub Problems}

(1) What are the technological leadership and it self-efficacy perceptions of educational managers?

(2) Does the technological leadership and IT self- efficacy perceptions of educational managers differ from those of seniority?

(3) Does the technological leadership and IT self- efficacy perceptions of educational managers differ by gender?

(4) Does the technological leadership and IT self- efficacy perceptions of educational managers differ by age?

(5) Is the technological leadership and IT self- efficacy perceptions of the educational managers different from the in-service training of the information technologies?

(6) Is there a relationship between the technological leadership self- efficacy perceptions of educational managers and the IT self- efficacy perceptions?

\section{Literature Review}

\section{Technological Leadership}

The most effective elements that can initiate change in schools are school administrators and teachers. It is important that school administrators and teachers acquire competence in this regard. The fact that school administrators have these competencies and a good educational leadership is not enough alone. They should also know the technology, understand and support the process of change (Sezer and Deryakulu, 2012). In other words, school administrators should also be technology leaders. Some of the features sought in the technology leader; to inspire and lead the best in the direction of a common goal to ensure the integration of technology, to support and maintain a detailed, level-appropriate and remarkable digital age learning environment, to support innovative learning environments, to undertake management and leadership to achieve common goals, and to design and develop an understanding for the development of technological culture (Bülbül ve Çuhadar, 2012). Managers should lead technology and encourage teachers to use technology in their lessons, and at the same time encourage them to receive training on this subject (Hacifazlıoğlu, Karadeniz and Dalgıç, 2011). They should be individuals who give importance to the use of information and communication technologies by avoiding traditional education. A good technology leader will significantly influence technology integration in schools and ensure that it becomes important. This is why it is necessary for school administrators to support technology integration in school management and classroom use as technology leaders and to help them gain the necessary competencies and gain these competencies. In the use of information and communication technologies, teachers and students in schools should lead 
(Bülbül and Çuhadar, 2012), in other words, lead the realization of technology integration in education.

\section{Technology Integration}

In addition to the definition of the technology integration process, Hew and Brush (2007) describe the integration as supporting the learning environment with technology in order to increase student success. By combining technology with specific designs and theories, it is expected that each student will be able to meet his / her needs and continue to achieve success. It is a natural requirement for the student to interact with content in order to better understand the issues. As a matter of fact, Cuban and his colleagues (2001) stated that in schools, students have low integration only when they use technology for research in internet. However, when they interact with content and view the internet as an environment to conduct their research, they expressed that high level integration was achieved. Alkan (1991), who has done the first studies on technology integration in schools in Turkey, clearly emphasizes the importance of ensuring that individuals receive higher quality education, meeting the needs of society, ensuring equal opportunity in education, and bringing technology to our classrooms. Accordin to Cradler (1996) elements to be considered for integrating technology into teaching; the needs of learners are listed as determining the needs and the path to practice in technology-oriented teaching programs, the available resources, and providing guidance and infrastructure for the teachers for their practice.

The main purpose of the integration is to diversify the educational environment and enrich the teaching materials by combining with technology. In the light of all definitions, it is observed that the common goal is to increase student success. The aim of this process is to enable students to integrate existing technologies with life. The use of technology actively, such as books and course materials, is one of the most important outcomes of integration. In the research conducted by Wo (2007), concluded that it is necessary to use all kinds of technology to support learning - teaching in technology integration. Inan and Lowther (2010) put together the technology integration process in three chapters. The first is that teachers use technology to plan, develop materials, interact and communicate with students within the framework of their teaching objectives. The second is to support the course work with presentation, materials and interactive content using technology. In the last title, it covers the use of technology as a cognitive support to improve students ' problem solving, algorithmic thinking skills, and facilitate critical and creative thinking. Bebell, Russell and O'dwyer (2004) described the integration as the use of technology when creating product outputs such as content preparation, technology support and plan creation. In general, it covers all activities in and out of the course. As a result of all these, Melmed (1995) emphasizes that the elements to be considered before realizing integration in a classroom should be in support of technology use, and that the main purpose in using technology should be to create positive results in student success, and resources should be created with a certain technology planning.

\section{Technology-Oriented Generations}

Technological developments in the 21 st century necessitate many changes in educational processes. Current curricula may be insufficient to meet the expectations of today's youth, which is called $\mathrm{Z}$ belt. To attract the attention of the $\mathrm{Z}$ generation, to support traditional methods, to enrich educational environments, it is necessary to rearrange educational environments and curricula to adapt to technological developments (Somyurek, 2014). People born in certain periods have dominant values, cultural perspectives, thinking and behavior styles. In these communities, they influenced the generation in which they lived, 
as well as the generation in which they lived with their thoughts and behaviors. Today, they are called X, Y and Z belts. Born in 1965-1980, X generation is a generation that has difficulty using technology and does not like change. The Y belt, born between 1980-1999, serves as a bridge between $\mathrm{X}$ and $\mathrm{Z}$ belts. The characteristics of this generation vary according to economic conditions in the region. Technology is a symbol of many things in their lives (Altuntuğ, 2012). After 2000, the group called $\mathrm{Z}$ belt, the most important feature distinguishes them from others is that they are in a constant and rapid change. It is a technology-dependent, hurried, internet-enabled consumer group that wants everything to be fast and fast (Yüzbaşığlu, 2012). The mission to the teacher was to be the person who did the teaching job. The student was the person who received the information transmitted by the teacher. This led the teacher to be active in this process and the student to be passive (Korkmaz, 2013). Today, individuals who take into consideration the individual differences of the middle of Education, who can think critically and creatively, who can access information and question it on their own are being trained. Great work falls on our teachers in this endeavor. Teachers have the ability to effectively use technological tools such as computers, Internet, interactive board etc., and it is necessary to train individuals who know the ways of reaching information and who can use this information correctly (Çakır and Yıldırım, 2009).

With technological developments in education, it has become easier to design the teaching process to appeal to all of our sensory organs, to concretize abstract concepts, and to learn meaningful, permanent and practical. This highlights the integration of digital technologies into education (Kaya and Yilayaz, 2013). In this paper, we will discuss the relationship between the learning process and the impact of the learning process on the learning environment. Digital natives are now called children who grow up with new technologies and are in harmony with virtual environments as soon as they are born. Digital immigrants; technological tools, web, internet, etc. after the age of 20 , the concepts are individuals who have a lower level of technological competence than the digital natives. The students who are growing up in today's technologies are unconsciously able to master the use of these technologies. In order to communicate well with students, teachers who are familiar with these technologies need to make changes in their course designs, materials used in the courses, and their course achievements. As a result, schools are equipped with the necessary, different, applicable technological tools, and designed to allow both learners and instructors to use these technologies effectively and efficiently both inside and outside the classroom constitute the main purpose of the technology integration.

\section{Method}

\section{Research Design}

This study is a descriptive survey research. In this context, we tried to determine the relationship between the technology leadership self-efficacy perceptions of educational managers and the IT self-efficacy perceptions.

\section{Study Group}

The study group consists of 210 managers, 85 school principal and 125 assistant principal working in Malatya city center. The study group consists of 23 female and 187 male managers. The distribution of the working group by age and branches is summarized in Table 1. 
Table 1. Distribution of participants by age and branches

\begin{tabular}{lrrrrrrrr}
\hline \multicolumn{1}{c}{ Age } & Presch. & $\begin{array}{c}\text { Prim. } \\
\text { Sch. }\end{array}$ & $\begin{array}{l}\text { Relig.- } \\
\text { philos. }\end{array}$ & $\begin{array}{l}\text { Turkish - } \\
\text { Soci. Sci. }\end{array}$ & Math. & Sci. & Other & Total \\
\hline 40 and under & 16 & 6 & 8 & 10 & 6 & 3 & 6 & 55 \\
41-50 & 6 & 52 & 10 & 14 & 11 & 16 & 16 & 125 \\
$\mathbf{5 1}$ and up & 1 & 14 & 2 & 1 & 4 & 2 & 6 & 30 \\
\hline Total & 23 & 72 & 20 & 25 & 21 & 21 & 28 & 210 \\
\hline
\end{tabular}

Vocational courses, art-work and physical education branches are grouped under the other heading. Table 2 summarizes the period of the working group in administration and their distribution to the school level.

Table 2. The school level of the participants according to the time spent in the administration

\begin{tabular}{lcccccc}
\hline $\begin{array}{c}\text { Time spent in the } \\
\text { administration }\end{array}$ & Presch. & $\begin{array}{c}\text { Prim. } \\
\text { Sch. }\end{array}$ & $\begin{array}{c}\text { Middle } \\
\text { Sch. }\end{array}$ & $\begin{array}{c}\text { Vocational } \\
\text { High School }\end{array}$ & $\begin{array}{c}\text { High } \\
\text { School }\end{array}$ & Total \\
\hline 1-5 years & 7 & 10 & 11 & 5 & 3 & 36 \\
6-10 years & 10 & 19 & 20 & 3 & 10 & 62 \\
10-19 years & 4 & 39 & 19 & 19 & 11 & 92 \\
20 years and more & 0 & 12 & 2 & 5 & 1 & 20 \\
\hline Total & 21 & 80 & 52 & 32 & 25 & 210 \\
\hline
\end{tabular}

\section{Data Collection Tools}

Research data were collected using the IT self-efficacy perception scale and the technology leadership self-efficacy scale.

Education managers technology leadership self-competence scale: Within the scope of the research, the scale developed by Hacifazlığlu, Karadeniz and Dalgıç (2011) has been used to determine the self-efficacy perceptions of educational managers regarding technology leadership. This scale is a Likert type scale consisting of 5 factors and 21 items in total. According to the validity and the reliability study conducted by the researchers, the internal consistency coefficient for the whole scale is $\alpha=0.97$. In addition to the scale, items aimed at determining the school level, title, District, year of service, type of school, gender, age, branch, graduated school and department, number of information technology classrooms in the school, educational status and in-service education status were added. Permission was obtained from the researchers for the use of the scale.

IT Self-efficacy perception scale: In the research, a Likert-type scale developed by Ekici, Ekici and Kara (2012) to determine self-efficacy perceptions for information technologies will be used to collect data. This scale consists of items 27 of which are positive and options (1) I definitely disagree, (2) I disagree, (3) I am indecisive, (4) I agree, (5) I absolutely agree. The high score from the scale indicates the high perception of the self-efficacy of the teachers. The researchers who developed the scale found Cronbach Alpha reliability coefficient of the scale as 0.97 . Researchers allowed to use the scale.

\section{Data Collection}

Data were collected by the researcher using scale forms for educational administrators who have decided to participate in the research on a voluntary basis. It took 23 minutes to fill out the scale forms. 


\section{Data Analysis}

The scores obtained in response to the responses of school administrators to five Likert-type scales do not show a standard quality due to the differences in the number of items in the factors. Therefore, the raw scores obtained were multiplied by 100 and used by dividing the number of items into 100 points. In order for parametric tests to be used in the analyzes, data must show normal distribution. Kolmogorov-Smirnov test and skewness coefficient were used to determine the normality of the collected data. The results of the Kolmogorov-Smirnov test are summarized in Table 3.

Table 3: Normality testing of data

\begin{tabular}{lccccc}
\hline Factors & Levene & df1 & df2 & P & Skewness \\
\hline Vision Leadership & 3,229 & 4 & 205 &, 013 &,- 508 \\
Digital Age Learning Culture & 5,099 & 4 & 205 &, 001 &,- 335 \\
Excellence In Professional Performance & 4,669 & 4 & 205 &, 001 &,- 763 \\
Systematic Development & 2,460 & 4 & 205 &, 047 &,- 426 \\
Digital Citizenship & 2,525 & 4 & 205 &, 042 &,- 545 \\
IT self-efficacy & 1,236 & 4 & 205 &, 297 &,- 508 \\
\hline
\end{tabular}

Table 3 shows that all factors related to technological leadership $(\mathrm{p}<0.05)$ show nonnormal distribution, while the IT self-efficacy perception scores ( $p>0.05)$ show normal distribution. However, when it is looked at skewness values for technological leadership factors, it is observed that these values are between +1.50 and -1.50 . According to Büyüközürk (2012), it is assumed that the skewness values between the number of layers $+1,50$ and $-1,50$ are also normal distributions. Therefore, it is assumed that the data collected about technological leadership factors show normal distribution characteristics. According to this data, parametric tests can be run by analyzign data. In this context, frequency, percent, Pearson correlation (r), t-test, one-way variance analysis (ANOVA) and LSD post-hoc analysis will be used in data analysis. Correlation and difference analysis showed that $\mathrm{p}<0.05$ significance level was significant.

\section{Results}

Findings on the technological leadership and it self-efficacy perceptions of school administrators are summarized in Table 4.

Table 4. Leadership and IT self-efficacy perceptions of school administrators

\begin{tabular}{|c|c|c|c|c|c|}
\hline & $\mathbf{N}$ & Min. & Max & $\bar{X}$ & Sd \\
\hline Vision Leadership & \multirow{7}{*}{210} & 25 & 100 & 75,64 & 18,97 \\
\hline Digital Age Learning Culture & & 30 & 100 & 78,22 & 15,90 \\
\hline Excellence In Professional Performance & & 28 & 100 & 77,98 & 16,35 \\
\hline Systematic Development & & 23 & 100 & 72,88 & 18,78 \\
\hline Digital Citizenship & & 28 & 100 & 75,39 & 19,24 \\
\hline Technological Leadership Self-efficacy & & 32 & 100 & 75,99 & 16,10 \\
\hline IT self- efficacy & & 42 & 100 & 84,60 & 11,90 \\
\hline
\end{tabular}

In Table 4, it is observed that the total scores of the school administrators' technological leadership self-perception change between 32 and 100, while the average is $\bar{X}=75.99$. It is observed that the highest average belongs to the digital age learning culture $(\bar{X}=78.22)$ and the lowest average belongs to the systematic development factor $(\bar{X}=72.88)$. It can be said that the technological leadership self-perceptions of school administrators are quite high. On the other hand, it is observed that the IT self-efficacy perceptions of school administrators towards using it are between 42 and 100 points and the average is $\bar{X}=84.60$. It can be said that 
school administrators have a high sense of self-efficacy for technological leadership and it use. Findings regarding the differentiation of the technological leadership and it self-efficacy perceptions of school administrators according to the time spent in the administration are summarized in Table 5.

Table 5. Leadership and IT self-efficacy perceptions according to the time spent in administration

\begin{tabular}{|c|c|c|c|c|c|c|c|c|c|}
\hline & & $\mathbf{N}$ & $\bar{X}$ & Sd & & & $\mathbf{N}$ & $\bar{X}$ & Sd \\
\hline \multirow{5}{*}{ 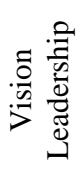 } & $1-5$ years & 36 & 79,72 & 18,32 & \multirow{5}{*}{ 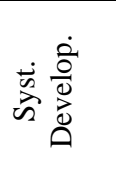 } & $1-5$ years & 36 & 79,50 & 16,38 \\
\hline & $6-10$ years & 62 & 74,44 & 16,87 & & $6-10$ years & 62 & 71,56 & 16,89 \\
\hline & $10-19$ years & 92 & 73,37 & 19,90 & & $10-19$ years & 92 & 70,15 & 19,43 \\
\hline & 20 years and high & 20 & 82,50 & 20,42 & & 20 years and high & 20 & 79,45 & 16,69 \\
\hline & Total & 210 & 75,64 & 18,96 & & Total & 210 & 73,06 & 18,26 \\
\hline \multirow{5}{*}{ 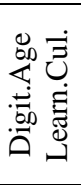 } & $1-5$ years & 36 & 81,67 & 15,69 & \multirow{5}{*}{ 焉 } & $1-5$ years & 36 & 79,56 & 17,62 \\
\hline & $6-10$ years & 62 & 77,53 & 13,21 & & $6-10$ years & 62 & 76,13 & 16,89 \\
\hline & $10-19$ years & 92 & 75,72 & 17,22 & & $10-19$ years & 92 & 72,65 & 20,10 \\
\hline & 20 years and high & 20 & 85,65 & 15,28 & & 20 years and high & 20 & 80,20 & 17,86 \\
\hline & Total & 210 & 78,22 & 15,90 & & Total & 210 & 75,58 & 18,67 \\
\hline \multirow{5}{*}{ 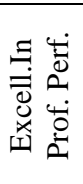 } & $1-5$ years & 36 & 81,56 & 16,23 & \multirow{5}{*}{ 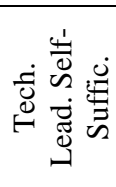 } & $1-5$ years & 36 & 80,50 & 15,72 \\
\hline & $6-10$ years & 62 & 78,52 & 12,40 & & $6-10$ years & 62 & 75,56 & 13,67 \\
\hline & $10-19$ years & 92 & 75,22 & 17,61 & & $10-19$ years & 92 & 73,12 & 17,31 \\
\hline & 20 years and high & 20 & 84,00 & 13,61 & & 20 years and high & 20 & 82,40 & 15,04 \\
\hline & Total & 210 & 78,11 & 15,81 & & Total & 210 & 75,99 & 16,06 \\
\hline \multirow{5}{*}{ 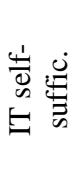 } & $1-5$ years & 36 & 84,06 & 12,24 & & & & & \\
\hline & $6-10$ years & 62 & 85,35 & 10,51 & & & & & \\
\hline & $10-19$ years & 92 & 84,20 & 12,54 & & & & & \\
\hline & 20 years and high & 20 & 85,05 & 13,09 & & & & & \\
\hline & Total & 210 & 84,60 & 11,90 & & & & & \\
\hline
\end{tabular}

In Table 5, it is observed that the management seniority interval is 20 years and higher and the lowest seniority interval is 10-19 years. In terms of self-efficacy perception scores for IT use, there are very small differences among management seniors. When the technological leadership factors are examined, it is observed that the highest average in all factors belongs to managers with a management seniority of 20 years and above, and the lowest average of managers with a management seniority of 10-19 years. The results of variance analysis regarding whether these differences are significant are summarized in Table 6.

Table 6. The impact of time spent in administration on leadership and IT self-efficacy

$$
\text { perceptions }
$$

\begin{tabular}{|c|c|c|c|c|c|c|c|}
\hline & & $\begin{array}{c}\text { Sum of } \\
\text { Squares }\end{array}$ & df & $\begin{array}{l}\text { Mean } \\
\text { Square }\end{array}$ & $\mathbf{F}$ & $\mathbf{p}$ & LSD \\
\hline \multirow[t]{3}{*}{ Vision Leadership } & Betw. Grp. & 2105,315 & 3 & 701,772 & 1,978 & ,118 & \multirow{3}{*}{-} \\
\hline & With. Grp & 73082,899 & 206 & 354,771 & & & \\
\hline & Total & 75188,214 & 209 & & & & \\
\hline \multirow{3}{*}{$\begin{array}{l}\text { Digital Age Learning } \\
\text { Culture }\end{array}$} & Betw. Grp. & 2137,286 & 3 & 712,429 & \multirow[t]{3}{*}{2,894} & \multirow[t]{3}{*}{,036 } & \multirow{9}{*}{$\begin{array}{l}\text { Between } 20 \text { and } \\
\text { high and 6-10, } \\
10-19 \text { years }\end{array}$} \\
\hline & With. Grp & 50706,638 & 206 & 246,149 & & & \\
\hline & Total & 52843,924 & 209 & & & & \\
\hline Excellence In & Betw. Grp. & 1901,232 & 3 & 633,744 & 2,592 & ,050 & \\
\hline Professional & With. Grp & 50360,025 & 206 & 244,466 & & & \\
\hline Performance & Total & 52261,257 & 209 & & & & \\
\hline Systematic & Betw. Grp. & 3226,253 & 3 & 1075,418 & \multirow[t]{3}{*}{3,333} & \multirow[t]{3}{*}{, 020} & \\
\hline \multirow[t]{2}{*}{ Development } & With. Grp & 66469,062 & 206 & 322,665 & & & \\
\hline & Total & 69695,314 & 209 & & & & \\
\hline \multirow[t]{3}{*}{ Digital Citizenship } & Betw. Grp. & 1803,198 & 3 & 601,066 & \multirow[t]{3}{*}{1,741} & \multirow[t]{3}{*}{,160 } & \\
\hline & With. Grp & 71119,926 & 206 & 345,242 & & & - \\
\hline & Total & 72923,124 & 209 & & & & \\
\hline \multirow{3}{*}{$\begin{array}{l}\text { Technological } \\
\text { Leadership Self- } \\
\text { efficacy }\end{array}$} & Betw. Grp. & 2323,254 & 3 & 774,418 & \multirow[t]{3}{*}{3,090} & \multirow[t]{3}{*}{,028 } & \multirow{3}{*}{$\begin{array}{l}\text { Betweeng10-19 } \\
\text { and } 1-5,20 \\
\text { years and high }\end{array}$} \\
\hline & With. Grp & 51630,727 & 206 & 250,635 & & & \\
\hline & Total & 53953,981 & 209 & & & & \\
\hline
\end{tabular}




\begin{tabular}{lllllll}
\hline IT self- efficacy & Betw. Grp. & 65,085 & 3 & 21,695 &, 151 & - \\
& With. Grp & 29573,511 & 206 & 143,561 & & \\
& Total & 29638,595 & 209 & & & \\
\hline
\end{tabular}

Table 6 shows that the technological leadership of school administrators differs significantly from that of self-efficacy perception scores $\left(\mathrm{f}_{(3-206)}=3,090 ; \mathrm{p}<0.05\right)$. According to the LSD results, significant differentiation is seen between managers with 10-19 years of executive rank and managers with 1-5 years and more than 20 years of senior rank. It is observed that different approaches are against managers with 10-19 years of executive rank. In this respect, it can be said that the technological leadership self-efficacy perceptions of managers who have graduated 1-5 and more than 20 years are significantly higher than the perceptions of managers who have graduated 10-19 years. When technological leadership sub-factors are examined, it is seen that there is not a differentiation factor according to seniority in terms of visionary leadership, and digital citizenship. It can be said that seniority managers have no influence on visionary leadership and self-efficacy perceptions of digital citizenship. Digital age learning culture $\left.\left(\mathrm{f}_{(3-206)}=2,894\right) ; \mathrm{p}<0,05\right)$, Excellence in professional practice $\left(\mathrm{f}_{(3-}\right.$ $206)=2,592 ; \mathrm{p}<0,05)$ and systematic development $\left(\mathrm{f}_{(3-206)}=3,333 ; \mathrm{p}<0,05\right)$ factors in school administrators' perception scores are significantly different compared to seniority. According to the LSD results, significant differentiation is seen between managers with 10-19 years of executive rank and managers with $1-5$ years and more than 20 years of senior rank. It is observed that different approaches are against managers with 10-19 years of executive rank. In this respect, it can be said that the digital age learning culture of managers who have graduated 1-5 and more than 20 years, excellence in professional practice and systematic development perceptions of self-efficacy are significantly higher than the perceptions of managers who have graduated 10-19 years. In addition, it is observed that the perception of self-efficacy of school administrators is not a difference in terms of seniority. Findings on whether educational managers' technological leadership and it self-efficacy perceptions differ according to gender are summarized in Table 7.

Table 7. The effect of gender on leadership and IT self-efficacy perceptions

\begin{tabular}{|c|c|c|c|c|c|c|c|}
\hline & Gender & $\mathrm{N}$ & $\bar{X}$ & $\mathrm{sd}$ & $\mathrm{t}$ & df & $\mathrm{p}$ \\
\hline \multirow[t]{2}{*}{ Vision Leadership } & Female & 23 & 75,22 & 16,47 & \multirow{2}{*}{,- 114} & \multirow{2}{*}{208} & \multirow[b]{2}{*}{,910 } \\
\hline & Male & 187 & 75,70 & 19,29 & & & \\
\hline \multirow[t]{2}{*}{ Digital Age Learning Culture } & Female & 23 & 77,74 & 16,61 & \multirow{2}{*}{,- 153} & \multirow{2}{*}{208} & \multirow{2}{*}{879} \\
\hline & Male & 187 & 78,28 & 15,85 & & & \\
\hline \multirow{2}{*}{$\begin{array}{l}\text { Excellence In Professional } \\
\text { Performance }\end{array}$} & Female & 23 & 78,09 & 15,00 & \multirow{2}{*}{, 033} & \multirow{2}{*}{208} & \multirow{2}{*}{,974 } \\
\hline & Male & 187 & 77,97 & 16,54 & & & \\
\hline \multirow[t]{2}{*}{ Systematic Development } & Female & 23 & 71,17 & 17,97 & \multirow{2}{*}{,- 461} & \multirow{2}{*}{208} & \multirow{2}{*}{,645 } \\
\hline & Male & 187 & 73,09 & 18,91 & & & \\
\hline \multirow[t]{2}{*}{ Digital Citizenship } & Female & 23 & 76,87 & 16,84 & \multirow{2}{*}{, 390} & \multirow{2}{*}{208} & \multirow{2}{*}{,697 } \\
\hline & Male & 187 & 75,21 & 19,54 & & & \\
\hline \multirow{2}{*}{$\begin{array}{l}\text { Technological Leadership Self- } \\
\text { efficacy }\end{array}$} & Female & 23 & 75,70 & 15,10 & \multirow{2}{*}{,- 093} & \multirow{2}{*}{208} & \multirow{2}{*}{,926 } \\
\hline & Male & 187 & 76,03 & 16,22 & & & \\
\hline \multirow[t]{2}{*}{ IT self-efficacy } & Female & 23 & 79,30 & 21,10 & \multirow{2}{*}{$-2,015$} & \multirow{2}{*}{208} & \multirow{2}{*}{045} \\
\hline & Male & 187 & 85,02 & 11,47 & & & \\
\hline
\end{tabular}

Table 7 shows that female $(\bar{X}=78.70)$ and male $(\bar{X}=76.03)$ school administrators are very close to one of the mean towards technological leadership and that there is no significant difference between them $\left.\left(\mathrm{t}_{(2-208)}=-0.093\right) ; \mathrm{p}>0.05\right)$. When the sub factors of technological leadership are examined, it is observed that the mean score of male and female school administrators in terms of any factors are not different. In this regard, it can be said that the technological leadership of school administrators is similar to the perceptions of self-efficacy. When IT self-efficacy perception scores are examined, it is seen that the mean score of female 
school administrators was $\bar{X}=79.30$ and the mean score of male school administrators was $\bar{X}$ $=85.02$. Since the $t$ test results were examined, this difference was significant $\left(t_{(2-28)}=-2015\right)$; $\mathrm{p}<0.05)$. Accordingly, significantly higher levels of female school administrators, male school administrators themselves perceive from the use of it can be said that as more than adequate. Findings on whether educational managers' technological leadership and it self-efficacy perceptions differ according to age are summarized in Table 8.

Table 8. Leadership and IT self-efficacy perceptions by age groups

\begin{tabular}{|c|c|c|c|c|c|c|c|c|c|}
\hline & & $\mathbf{N}$ & $\bar{X}$ & S.s & & & $\mathbf{N}$ & $\bar{X}$ & S.s \\
\hline \multirow{4}{*}{ 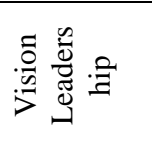 } & 40 and under & 55 & 76,27 & 18,28 & \multirow{4}{*}{ 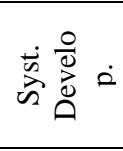 } & 40 and under & 55 & 74,16 & 15,93 \\
\hline & $41-50$ & 125 & 76,12 & 17,55 & & $41-50$ & 125 & 72,50 & 20,28 \\
\hline & 51 and up & 30 & 72,50 & 25,31 & & 51 and up & 30 & 72,10 & 17,49 \\
\hline & Total & 210 & 75,64 & 18,96 & & Total & 210 & 72,88 & 18,78 \\
\hline \multirow{4}{*}{ 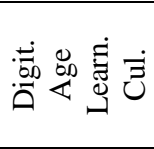 } & 40 and under & 55 & 79,09 & 15,37 & \multirow{4}{*}{ 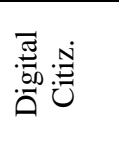 } & 40 and under & 55 & 76,80 & 17,49 \\
\hline & $41-50$ & 125 & 78,05 & 15,55 & & $41-50$ & 125 & 74,82 & 20,34 \\
\hline & 51 and up & 30 & 77,33 & 18,56 & & 51 and up & 30 & 75,20 & 17,96 \\
\hline & Total & 210 & 78,22 & 15,90 & & Total & 210 & 75,39 & 19,23 \\
\hline \multirow{4}{*}{ 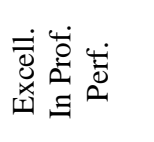 } & 40 and under & 55 & 78,55 & 15,98 & \multirow{4}{*}{ 巳் } & 40 and under & 55 & 76,96 & 15,35 \\
\hline & $41-50$ & 125 & 78,14 & 16,49 & & $41-50$ & 125 & 75,84 & 16,17 \\
\hline & 51 and up & 30 & 76,27 & 16,80 & & 51 and up & 30 & 74,83 & 17,31 \\
\hline & Total & 210 & 77,98 & 16,34 & & Total & 210 & 75,99 & 16,06 \\
\hline \multirow{4}{*}{ 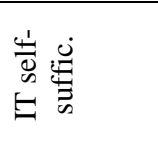 } & 40 and under & 55 & 84,27 & 12,71 & & & & & \\
\hline & $41-50$ & 125 & 85,48 & 10,53 & & & & & \\
\hline & 51 and up & 30 & 80,10 & 20,15 & & & & & \\
\hline & Total & 210 & 84,40 & 12,93 & & & & & \\
\hline
\end{tabular}

Table 8 shows that the mean of self-efficacy perception scores is slightly higher in school administrators aged 40 and below. In terms of self-efficacy perception scores for it use, it is observed that school administrators in the age group 41-50 have a slightly higher scores compared to other age groups. The results of variance analysis regarding whether these differences are meaningful are summarized in Table 9.

Table 9. The effect of age groups on leadership and IT self-efficacy perceptions

\begin{tabular}{|c|c|c|c|c|c|c|c|}
\hline & & $\begin{array}{l}\text { Sum of } \\
\text { Square }\end{array}$ & df & $\begin{array}{l}\text { Mean } \\
\text { Square }\end{array}$ & $\mathbf{F}$ & $\mathbf{p}$ & LSD \\
\hline \multirow[t]{3}{*}{ Vision Leadership } & Betw. Grp. & 346,605 & 2 & 173,303 & ,479 & ,620 & \\
\hline & With. Grp & 74841,609 & 207 & 361,554 & & & - \\
\hline & Total & 75188,214 & 209 & & & & \\
\hline \multirow{3}{*}{$\begin{array}{l}\text { Digital Age Learning } \\
\text { Culture }\end{array}$} & Betw. Grp. & 69,000 & 2 & 34,500 & ,135 & ,874 & \\
\hline & With. Grp & 52774,924 & 207 & 254,951 & & & - \\
\hline & Total & 52843,924 & 209 & & & & \\
\hline \multirow{3}{*}{$\begin{array}{l}\text { Excellence In } \\
\text { Professional } \\
\text { Performance } \\
\end{array}$} & Betw. Grp. & 109,013 & 2 & 54,506 & 202 & ,817 & \\
\hline & With. Grp & 55738,911 & 207 & 269,270 & & & - \\
\hline & Total & 55847,924 & 209 & & & & \\
\hline \multirow{3}{*}{$\begin{array}{l}\text { Systematic } \\
\text { Development }\end{array}$} & Betw. Grp. & 126,549 & 2 & 63,274 & , 178 & 837 & \\
\hline & With. Grp & 73599,475 & 207 & 355,553 & & & - \\
\hline & Total & 73726,024 & 209 & & & & \\
\hline \multirow[t]{3}{*}{ Digital Citizenship } & Betw. Grp. & 151,613 & 2 & 75,806 & ,203 & ,816 & \\
\hline & With. Grp & 77210,368 & 207 & 372,997 & & & - \\
\hline & Total & 77361,981 & 209 & & & & \\
\hline \multirow{3}{*}{$\begin{array}{l}\text { Technological } \\
\text { Leadership Self- } \\
\text { efficacy }\end{array}$} & Betw. Grp. & 95,087 & 2 & 47,544 & , 183 & ,833 & \\
\hline & With. Grp & 53858,894 & 207 & 260,188 & & & - \\
\hline & Total & 53953,981 & 209 & & & & \\
\hline \multirow[t]{3}{*}{ IT self-efficacy } & Betw. Grp. & 701,386 & 2 & 350,693 & 2,118 & ,123 & \\
\hline & With. Grp & 34270,809 & 207 & 165,559 & & & - \\
\hline & Total & 34972,195 & 209 & & & & \\
\hline
\end{tabular}

In Table 9, it is observed that there is no significant difference in both the technological leadership of school administrators in terms of total and factor scores and it self-efficacy 
perception scores compared to age groups. It can be said that school administrators of age groups have no influence on technological leadership and it self-efficacy perceptions. Findings on whether educational managers' technological leadership and it self-efficacy perceptions differ according to the situation of receiving in-service training are summarized in Table 10.

Table 10. Effect of in-service training on leadership and IT self-efficacy perceptions

\begin{tabular}{|c|c|c|c|c|c|c|c|}
\hline & $\begin{array}{l}\text { in-service } \\
\text { training }\end{array}$ & $\mathrm{N}$ & $\bar{X}$ & sd & $\mathrm{t}$ & df & $\mathrm{p}$ \\
\hline \multirow[t]{2}{*}{ Vision Leadership } & Receive & 184 & 75,65 & 19,16 & \multirow{2}{*}{, 019} & \multirow{2}{*}{208} & \multirow{2}{*}{,985 } \\
\hline & Not receive & 26 & 75,58 & 17,85 & & & \\
\hline \multirow[t]{2}{*}{ Digital Age Learning Culture } & Receive & 184 & 78,00 & 16,25 & \multirow{2}{*}{,- 530} & \multirow{2}{*}{208} & \multirow{2}{*}{, 597} \\
\hline & Not receive & 26 & 79,77 & 13,27 & & & \\
\hline \multirow{2}{*}{$\begin{array}{l}\text { Excellence In Professional } \\
\text { Performance }\end{array}$} & Receive & 184 & 77,76 & 16,60 & \multirow{2}{*}{,- 518} & \multirow{2}{*}{208} & \multirow{2}{*}{,605 } \\
\hline & Not receive & 26 & 79,54 & 14,59 & & & \\
\hline \multirow[t]{2}{*}{ Systematic Development } & Receive & 184 & 72,44 & 19,22 & \multirow{2}{*}{,- 904} & \multirow{2}{*}{208} & \multirow{2}{*}{, 367} \\
\hline & Not receive & 26 & 76,00 & 15,27 & & & \\
\hline \multirow[t]{2}{*}{ Digital Citizenship } & Receive & 184 & 75,26 & 19,62 & \multirow{2}{*}{,- 259} & \multirow{2}{*}{208} & \multirow{2}{*}{,796 } \\
\hline & Not receive & 26 & 76,31 & 16,54 & & & \\
\hline \multirow{2}{*}{$\begin{array}{l}\text { Technological Leadership Self- } \\
\text { efficacy }\end{array}$} & Receive & 184 & 75,77 & 16,34 & \multirow{2}{*}{,- 537} & \multirow{2}{*}{208} & \multirow{2}{*}{, 592} \\
\hline & Not receive & 26 & 77,58 & 14,08 & & & \\
\hline \multirow[t]{2}{*}{ IT self-efficacy } & Receive & 184 & 84,71 & 13,17 & \multirow{2}{*}{,944 } & \multirow{2}{*}{208} & \multirow{2}{*}{, 346} \\
\hline & Not receive & 26 & 82,15 & 11,05 & & & \\
\hline
\end{tabular}

In Table 10, although there are small differences between technological leadership and it selfefficacy scores according to the situation of school administrators receiving in-service training on the use of it technologies, it is seen that these differences are not significant. According to this, it can be said that school administrators who have received and not received in-service training have similar perceptions of self-efficacy towards technological leadership and it use. The findings regarding the relationship between the technological leadership self-efficacy perceptions of educational managers and the IT self-efficacy perceptions are summarized in Table 11.

Table 11. Relationship between technological leadership and IT self-efficacy scores

\begin{tabular}{llc} 
& & IT self-efficacy \\
\hline Vision Leadership & $\mathrm{r}$ &, $251(* *)$ \\
Digital Age Learning Culture. & $\mathrm{r}$ &, $339(* *)$ \\
Excellence In Professional Performance & $\mathrm{r}$ &, $294(* *)$ \\
Systematic Development & $\mathrm{r}$ &, $369(* *)$ \\
Digital Citizenship & $\mathrm{r}$ &, $270(* *)$ \\
Technological Leadership Self-efficacy & $\mathrm{r}$ &, $341(* *)$ \\
& &
\end{tabular}

$* * \mathrm{p}=0,000, \mathrm{~N}=210$

In Table 11, there is a significant positive correlation between it self-efficacy scores and technological leadership total scores as well as all factors scores. It can be said that when the levels of it self-efficacy perception of school administrators are increased, the levels of technological leadership self-perception are also increased. 


\section{Conclusion, Discussion and Recommendations}

Self-efficacy perceptions of school administrators towards technological leadership and IT use are very high. In the research carried out by Bostanci (2010) to examine the characteristics of technological leadership of school administrators, similar findings were obtained. In this study, it was concluded that the technological leadership levels of school administrators were significantly higher. In the study of technological leadership of school administrators in high schools conducted by Seay (2004), it was concluded that the perceptions of school administrators regarding technological leadership were quite high. In another study conducted by Weber (2006) on the use of computer technologies of state elementary school administrators and technological leadership levels, it is observed that same results were achieved. Marulcu (2010) carried out a study to reveal the relationship between the socio-economic levels of the students, the technology infrastructure and the leadership characteristics of the managers and school technology. He found that the leadership characteristics of school principals alone influenced school technology outcomes. However, Ergişi (2005) conducted research on the effective use of IT technologies in schools to determine the technological competencies of school administrators and concluded that school administrators used technology mostly in management work and did not pay much attention to educational use. In this research, the high level of technological leadership self-efficacy of school administrators demonstrates that they are willing and supportive to use it technology not only in managerial tasks but also in educational processes.

The technological leadership perceptions of managers with 1-5 and more than 20 years of managerial experience are significantly higher than the perceptions of managers with 10-19 years of seniority. Technological leadership factors are examined; it was concluded that seniority managers have no influence on visionary leadership and digital citizenship selfefficacy perceptions, and managers with more than $1-5$ and 20 years of seniority, digital learning culture, excellence in professional practice, and systematic self-efficacy perceptions are significantly higher than those of managers with 10-19 years of seniority.

The fact that the school administrators, who had just started working as a manager, had made special preparations in order to be successful in the exams that they entered in order to be the manager and their willingness to develop individual skills related to management may have caused the high level of self-efficacy perception of technological leadership. On the other hand, the fact that school administrators, who have been managers for more than 20 years, have reached vocational maturity due to their seniority, may have led to a positive perception of technological leadership self-efficacy. On the other hand, the school administrators' use of IT self-efficacy perceptions does not differ according to seniority. In a study conducted by Bostanci (2010), it was determined that there was a positive relationship between technological leadership competencies and sub-dimensions of school administrators and management and teaching time. It is observed that overall technological leadership competencies of school administrators differ significantly from management seniority. When examined together with the sub-dimensions, it was determined that all sub-dimensions differ in the high confidence interval according to the duration of the management.

Female's and male's school administrators' perceptions of technological leadership selfefficacy are similar. However, male school administrators perceive it as more significant than female school administrators. In the literature, it is possible to come across different researches that support and does not support this finding. Bozdoğan and Uzoğlu (2012) examined teacher candidates' attitudes towards computer use in terms of different variables. It was found that the mean score of male teacher candidates for computer use was higher than 
female teacher candidates in terms of gender. On the other hand, Dasdemir, Cengiz, Uzoğlu and Bozdoğan (2012) examined the opinions of science and technology teachers about the tablet computer used in schools within the scope of FATIH Project. It was concluded that the supporting status of science and technology teachers in the use of tablet computers in the courses did not differ from gender, professional experience, the situation of having a computer, the purpose of computer usage and the duration of computer usage. In the study conducted by Bostanci (2010), more male school administrators were trained in technology management than women, there was a relationship between gender and education in technology management, and there was a relationship between gender and leadership.

Age groups and in-service training situations do not differentiate school administrators' technological leadership and it self-efficacy perceptions. In the literature, it is possible to find the opposite results of these findings. For example, Van Braak, Tondeur and Valcke (2004) conducted a study to examine the relationship between teachers' demographics (age and gender), computer experiences and attitudes and their use of computers. They concluded that teachers' attitudes towards computer education and use of computers in education have a direct and powerful impact on computer usage in classrooms. Moreover, Dasdemir, Cengiz, Izoğlu and Bozdoğan (2012) concluded that teachers' views on information technologies differ in terms of the graduation branch and the frequency of computer use. In addition, computer attitude scores were examined according to the situation in which science and technology teachers need to receive in-service training in the use of tablet computers from science and technology courses and the mean score of teachers who need and do not express ideas were found to be close to each other. There was a significant difference between the teachers' computer attitude scores and the cases of supporting tablet computers. In the study conducted by Bostanci (2010), it was stated that the overall technological leadership competencies of school administrators differ significantly from the age factor. In this study, it was found that technological leadership competencies in learning and teaching, support services and management, measurement and evaluation activities differ significantly from age variables. There was a significant difference between school administrators in 35-45 and 4560 age groups and administrators in 20-35 age groups in favor of high age groups in terms of technological leadership competencies. In terms of sub-dimensions, it has been observed that school administrators in the age of 45-60 years in terms of learning and teaching have higher proficiency than younger managers; in the age of 20-35 years in support services have lower competence than the age group. In this study, the high perception of self-efficacy for both technological leadership and it use of school administrators could have led to the elimination of the expected differences in many demographic characteristics.

There was a significant positive correlation between technological leadership and IT selfefficacy perceptions. When it self-efficacy perception levels of school administrators rise, technological leadership levels rise as well. This finding is consistent with the literature. Robinson (2003) conducted a study to reveal the relationship between teachers' demographic characteristics, computer proficiency levels, external support variables and their perception of computer use and using computer in the classroom. It was found that there was a significant correlation between the teachers' effective use of technology and computer proficiency levels. Moreover, Tondeur, Van Keer, Van Braak and Valcke (2008), concluded that the technology plan in the effective use of technology in lessons has important implications for IT support and education. Within this framework, the following points may be suggested:

1. In-service training activities related to technological leadership characteristics should be organized for training managers. 
2. In-service training activities related to IT use that are already being organized should be continued with more intensive content.

\section{References}

Alkan, C. (1991). Computer Aided Learning Modules. Ankara: An1 Pub.

Altuntuğ, N. (2012). The consumption phenomenon from generation to generation and the consumer profile of future. Journal of Organization and Management Science, 4(1):203-212.

Bebell, D. R. (2004). Measuring teachers' technology uses: Why multiple measures are more revealing. Journal of Research on Technology in Education, 45-63.

Bostanc1, H. (2010). A review on school principals in terms of technology leadership adequacy. Unpublished Master Thesis, Gazi University, IT Institute, Ankara

Bozdoğan, A. E. \& Uzoğlu, M. (2012). The examination of preservice science teachers' computer using attitudes in terms of different variables. EÜ - Science Institute Journal, 5(2), 213-227.

Bülbül, T. \& Çuhadar, C. (2012). Analysis of The Relationship Between School Administrators' Perceptions of Technology Leadership Self-Efficacy and Their Acceptance of ICT. Mehmet Akif Ersoy Un. Journal of Education Faculty, 23, 474499.

Büyüköztürk, S. (2012). Sosyal Bilimler İçin Veri Analizi El Kitabı [Manual of data analysis for social sciences], 17. Press. Ankara: Pegem Academic Pub.

Çakır, R. \& Yıldırım, S. (2009). What Do Computer Teachers Think About the Factors Affecting Technology Integration in Schools?. Elementary Education Online, 8(3), 952-964.

Çakıroğlu, Ü., Gökoğlu, S. \& Çebi, A. (2015). Basic indicators for teachers' technology integration: a scale development study. GUJGEF 35(3): 507-522.

Cradler, J. (1996). Implementing technology in education: Recent findings from research and evaluation studies. http://www.wested.org/techpolicy/refind.html

Cuban, L. K. (2001). High access and low use of technology in high school classrooms: Explaining an apparent paradox. American Educational Research Journal, 813-834.

Daşdemir, İ., Cengiz, E., Uzoğlu, M. \& Bozdoğan, A. E. (2012). Examination of science teachers' opinions related to tablet pcs using in science and technology courses. Mustafa Kemal University Journal of Social Sciences Institute, 9(20): 495-511.

Daşdemir, İ., Uzoğlu, M. \& Cengiz, E. (2012). The Effect of Use of Animations in Unit of Body Systems on the Academic Achievements of The 7th Students, Retention of the Knowledge Learned, and the Scientific Process. Trakya Un.Journal of Education Faculty, 2(2), 54-62.

Demir, S. \& Bozkurt, A. (2011). Primary mathematics teachers' views about their competencies concerning the integration of technology. Elementary Education Online, 10(3), 850-860.

Ekici, E., Ekici, F. T., \& Kara, İ. (2012). Validity and Reliability Study of ICT Self-Efficacy Perception Scale for Teachers. Pamukkale Un. Journal of Education Faculty, 31(1): 53-65.

Ergişi, K. (2005). Determining the technological competences of school administrators on the effective use of information technologies in school. Unpublished master Thesis, Kırıkkale Un, Kirıkkale.

Hacıfazlığlu, Ö. Karadeniz, Ş. \& Dalgıç, G. (2011). School Administrators' Perceptions of Technology Leadership: An Example for Metaphor Analysis. Journal of Educational Sciences Research, 1(1), 97-121. 
Hew, K. F \& Brush, T. (2007). Integrating Technology into K-12 Teaching and Learning: Current Knowledge Gaps and Recommendations for Future Research. Educational Technology Research and Development, v55 n3 p223-252

İnan, F. A., \& Lowther, D. L. (2010). Factors affecting technology integration in K-12 classrooms: A path model. Educational Technology Research and Development, 58(2), 137-154.

Kabakçı Yurdakul, I. (2011). Examining technopedagogical knowledge competencies of preservice teachers based on ict usage. H. U. Journal of Education, 40, 397-408.

Kaya, Z., \& Y1layaz, Ö. (2013). Technology integration models in teacher education and technological pedagogical content knowledge. Journal of Western Anatolian Educational Sciences, 4(8): 57-83.

Korkmaz, Ö. (2013). İlk ve Orta Öğretimde Öğretimsel Amaçlı Teknoloji Kullanımı [ Use of Technology for teaching in Primary and Secondary Education.]. Kürşat Çağıltay ve Yüksel Göktaş (Ed.). Öğretim Teknolojilerinin Temelleri: Teoriler, Araştırmalar, Eğilimler [Fundamentals of Instructional Technologies: Theories, Researches, Trends] (p. 431-446). Ankara: Pegem Academic Pub.

Marulcu, İ. (2010). Educational leadership and use of technology. Unpublished Master Thesis, Süleyman Demirel Un., Isparta.

Melmed, A. E. (1995). The Costs and Effectiveness of Educational Technology. Proceedings of a Workshop. DRU-1205-CTI, Santa Monica: RAND Corporation.

Robinson, W. I. (2003). External, and internal factors which predict teachers' computer usage in K-12 classrooms. Unpublished doctoral dissertation, Wayne State University, Detroit

Şahin, S. \& Aslan, N . (2008). A Qualitative Study on the Opinions of Secondary School Principals Regarding Strategic Planning. Gaziantep University Journal of Social $\begin{array}{lllll}\text { Sciences, } & 7 & (1), & 172-189 . & \text { Retrieved }\end{array}$ http://dergipark.gov.tr/jss/issue/24257/257122

Seay, D. A., (2004). A study on technology leadership of high school school administrators in Texas. . Unpublished PhD Thesis, Nort Teksas Un.

Sezer, B. \& Deryakulu, D. (2012). The competencies of elementary school administrators regarding their technology leadership roles. Educational Technology Teory and Practice, 2(2), 70-92.

Somyürek, S. (2014). Gaining the attention of generation $\mathrm{z}$ in learning process: augmented reality. Educational Technology Teory and Practice, 4(1), 63-80.

Tondeur, J., Valcke, M., \& Van Braak, J. (2008). A multidimensional approach to determinants of computer use in primary education: Teacher and school characteristics. Journal of Computer Assisted Learning, 24(6), 494-506

Usta, E. \& Korkmaz, Ö. (2010). Pre-service teachers' computer competencies, perception of technology use and attitudes toward teaching career. International Journal of Human Science, 7(1), 1335-1349.

Van Braak, J., Tondeur, J., \& Valcke, M. (2004). Explaining different types of computer use among primary school teachers. European Journal of Psychology of Education, 19(4), 407-422.

Weber, M. J., (2006). A study of computer technology use and technology leadership of Texas elementary public school principals", Unpublizhed PhD Thesis, Nort Teksas Un.

Woo, W. (2007). Systematic planning for ICT integration in topic learning. . Educational Technology \& Society, 148-156. 
Yüzbașıgloglu, S. (2012). Kuşaklar X, Y, Z Diye Ayrıștı Pazarlamacıların Kafası Karıs,tı [Generations $\mathrm{X}, \mathrm{Y}, \mathrm{Z}$ Separated, Marketers Confused], http://www.dunya.com/print.php?type=1\&id=151507 